\author{
산불방지 급수시설 설치 기준 마련에 관한 연구 \\ 김동현 ${ }^{\dagger}$ 남송희 $*$ 금시훈* \\ 국제응용시스템분석연구원 생태계서비스관리 - 국립산림과학원 산림방재연구과, *산림청 산불방지과
}

\title{
Study on Guideline of Water Supply System for Forest Fire Dong-Hyun $\mathrm{Kim}^{\dagger} \cdot$ Song-Hee Nam* - Si-Hoon Keum*
}

Ecosystems Services and Management, International Institute for Applied Systems Analysis . Dept. of Forest Disaster, Korea Forest Research Institute *Dept. Forest Fire Prevention, Korea Forest Service

(Received March 20, 2013; Revised June 4, 2013; Accepted June 14, 2013)

$$
\text { 요 약 }
$$

산불로부터 주요 산림과 시설물들을 보호하고 주변 확산을 저지하기 위해서는 상설 급수 및 살수시설이 반드시 필요 하다. 우리나라에서는 2005년 양양산불로 인해 낙산사 소실을 경험하면서 주요문화재 건축물 주변에 숲 관리와 함께 산 불방지 급수시설 설치사업을 단계적으로 실시하였다. 하지만 기존 설치된 산불방지급수시설의 경우, 별도의 설치와 관리 를 위한 기준을 마련하지 않고 각 시공업체의 시방서를 기준으로 설치하였다. 시공업체의 시방서는 NFSC 109 를 토대로 산림지역에 변형하여 설치한 것으로 광범위한 산불확산으로부터 주요시설물 등을 효과적으로 보호하기에는 방호면적이 적고 호스의 이동과 동시살수에 있어 제한적인 단점들을 가지고 있다. 이에 본 연구에서는 국내에서 설치되어 이용하고 있는 산불방지 급수전의 실태조사를 실시하여 문제점들을 도출하였고 이를 보완할 수 있는 성능위주의 산불방지 급수시 설 기준을 마련하였다. 그 결과, 산불방지 효과를 높이기 위한 방법으로 산불방지 급수시설의 구성을 수관화 확산방지를 위한 'Water Sprinkler Tower System', 지표화 진화를 위한 'Forest Fire Hydrant System', 'Portable Water Spray System' 3가지를 제시하였고 설치를 위한 펌프의 성능 및 부속품들에 대한 기준을 제시하였다.

\section{ABSTRACT}

Permanent water supply and water sprinkling systems are essential to protect major forests and facilities from forest fire. Back in 2005, Naksan Temple, a valuable cultural asset of Korea, was burned down in a forest fire that took place in Yangyang. This started a series of movements including installing water supply facilities and managing forests near important cultural assets. As for the existing facilities, however, they were installed without any standard guidelines for management and installation according to each constructor's specifications, which were based on the National Fire Safety Code 109. Unfortunately, this is not effective in protecting facilities from forest fires such as they have a small protection area, limited simultaneous sprinkling, and a difficult the movement of fire hose. Against this background, the study examines the condition of water supply facilities currently in use, identifies their deficiencies, and suggests how to improve the criteria for water supply service to effectively prevent forest fire. Specifically, three systems were proposed: Water Sprinkler Tower System for preventing spread of crown fires, and Forest Fire Hydrant System and Portable Water Spray System to be effective for suppressing surface fires. In addition, the standards on the performance and components of water pumps are also suggested.

Keywords : Forest fire, Water supply system, Fire protection, Fire suppression, Forest fire guideline

\section{1. 서 론}

\section{1 연구 배경 및 목적}

산불은 일반화재와는 다른 확산패턴을 가진다. 일반화재 는 내화구조물 또는 단일 건물로 구획된 제한적 공간에서 의 화재로 소방시설의 사전 설치로 조기 감지 및 초기진화

\footnotetext{
Corresponding Author, E-Mail: k3d2h1@forest.go.kr

TEL: +82-2-961-2686, FAX: +82-2-961-2699
}

가 가능하며 구획된 공간에서만 확산이 이루어진다. 하지 만 산불은 산림지역이 넓게 분포되어 있고 기상과 지형 등 외부 환경에 의해 크게 산불행태(Fire Behavior)가 달라진 다. 또한 일반화재와는 다르게 수 수십 킬로미터에 걸쳐 확산이 빠르게 이루어진다 ${ }^{(1)}$.

우리나라에서 발생한 산불사례 중 최고 산불확산속도는

ISSN: $1738-7167$

DOI: http://dx.doi.org/10.7731/KIFSE.2013.27.3.038 
$8.8 \mathrm{~km} / \mathrm{h}$, 불씨가 다른 지역으로 날아가 확산되는 비화거리 는 최대 $2 \mathrm{~km}$ 로 조사된 바 있다 ${ }^{(2)}$. 산불발생 후 효과적으로 진화하기위해서는 산불확산을 예측하고 장비와 인력 이동 을 보다 빠르게 운영할 필요가 있다. 하지만 광역의 산림지 역에서 지상진화자원을 이용하여 산불을 진화하기에는 위 험성과 함께 한계성을 가지고 있다 ${ }^{(3)}$. 따라서 주요사찰, 위 험물시설 등의 주요 시설과 산림보호지역에 대해서는 산불 방지를 위한 살수 및 수원공급설비와 같은 고정시설이 절 실히 필요하다. 기존 연구된 산림인접지의 위험도 평가결 과에서 산불로부터 피해를 입은 시설물뿐만 아니라 미피해 시설물에서도 위험성이 높은 것으로 나타났다 ${ }^{(4)}$.

미국의 경우, 산림인접지역에서의 2층 이상 또는 $9.144 \mathrm{~m}$ 이상인 건축물에 대해서는 자동스프링클러 살수설비를 하 도록 규정하고 있다(NFPA 1141, National Fire Protection Association) $)^{(5)}$. 또한 낙차압을 이용한 물 공급을 위해 저 수탑을 설치하거나 이와 같은 기능을 가진 저수조 설치를 규정하고 있으며 도시형 급수시스템 설치의 경우, $20 \mathrm{psi}$ 수압으로 최소 1 시간 이상 물을 공급할 수 있는 양을 확보 하여야 한다 ${ }^{(5)}$. 우리나라의 경우, 2005년 4월 4일 발생한 강원도 양양산불로 인해 낙산사가 소실된 이후 산림청에 서는 2006년부터 산불로부터 산림인접지 주요시설물 보호 및 주요산림지역 보호를 목적으로 산불방지 급수시설을 2011년까지 6년간 28개소를 설치 운영하고 있다. 하지만 산불과 같이 길고 넓은 화염확산을 진화하는데 있어서는 한계가 있다. 또한 기존 시설물의 경우, 소화용수 저장용 량, 호스 규격, 펌프의 성능, 기타 관 부속품 및 기계실의 운영관리에 대한 규격 및 기준이 마련되어 있지 않다.

이에 본 연구에서는 산림인접지 또는 산림내 주요시설 물, 산림 등을 산불로부터 보호하기위해 산불방지 급수시 설에 관한 기준을 제안하였다.

\section{2 연구 방법}

일반화재의 소화설비의 경우에는 '소방시설 설치 · 유지 및 안전관리에 관한 법률'로 제정되어 시설의 설치 및 유 지관리에 엄격히 규제가 이루어지고 있다. 하지만 우리나 라 산불현장에서 활용하고 있는 시설 및 장비들은 자체 내 부규정에 의해 운영되고 있는 실정이다. 실제 산불진화를
위한 급수시설 또는 살수장치는 다음과 같은 기능들을 고 려할 필요가 있는 것으로 사전 조사되었다. 1) 산불진화호 스의 유효 이동거리를 최소 $500 \mathrm{~m}$ 이상 확보, 2) 산악지대 의 고도차에 따른 양정을 펌프성능에 반영, 3) 산림내 이 동이 가능하도록 가볍고 일정 방수압, 방수량의 성능을 확 보, 4) 자동 살수를 통한 산불제어 등의 기능이 필요하다. 이에 본 연구에서는 산불방지급수시설 기준마련을 위하여 첫째, 기존 시설의 설치규격 및 사용실태 조사를 통한 문 제점 분석을 실시하였고 둘째, 산불방지 급수시설 기준마 련의 필요성과 기능에 대한 산블담당 공무원 및 진화전문 가에 대해 설문조사를 실시하였으며 셋째, 기존 산불방지 급수시설에서 설문조사에서 요구한 필요한 기능들이 반영 된 살수설비 3 가지를 구성하였고 넷째, 이에 따른 설치기 준을 제안하였다.

\section{2. 급수시설 사례조사 및 문제점}

\section{1 사례조사}

2005년 양양산불로 인한 낙산사 소실이후 산림청과 문 화재청은 산불로부터 주요보호시설 및 사찰문화재 피해방 지하기 위해 '산불방지 급수시설'을 단계적으로 설치하고 있다.

본 연구에서는 기존 '산불방지 급수시설' 현황을 조사하 기 위해 문화재청에서 설치한 1 개소와 산림청에서 설치한 5 개소에 대해 산불방지용 급수시설 현장 설치 및 운영 사 례조사를 실시하였다(Table 1). 이중 충남 공주시 사곡면 마곡사는 문화재청에서 시행한 사업으로 다른 사찰지역도 소방방재청 옥외소화전설비의 화재안전기준(NFSC 109) ${ }^{(6)}$ 에 따라 설치되었기에 1 개소에 대해서만 조사를 실시하였 다. 산림청에서 설치한 산림품종관리센터 및 금봉자연휴양 림, 안면도 채종원, 좌구산자연휴양림, 고성군 현내면 $\mathrm{DMZ}$ 등 5 개소는 설치 기준 없이 일반 시설공사 시방서 기준에 의해 설치되었다 ${ }^{(7,8)}$.

기존 설치된 '산불방지 급수시설' 6 개소에 대한 사례조 사 결과, Table 2에 나타난 바와 같이 시행부처에 따라 설 치기준이 다르고 설치기준이 없는 5 개소의 경우에는 시설 공사 시방서에 따라 각기 다른 기준의 펌프성능 및 방식,

Table 1. Case Studies for the Existing Forest Fire Water Supply System

\begin{tabular}{|c|c|l|c|c|c|}
\hline \hline No. & Year & Location & Protection Objects & Type & Reg. \\
\hline 1 & 2008 & Sagok, Gongju Chungnam (Magoksa temple) & Temple & Facility & NFSC 109 \\
\hline 2 & 2009 & Chungju, Chungbook (KFSV*) & Seed forest & Forest & no \\
\hline 3 & 2010 & Kosung, Kangwondo (DMZ) & Military zone & Forest & no \\
\hline 4 & 2011 & Jeungpueong, Chungbook (Jwagu lodge) & Forest lodge & Facility & no \\
\hline 5 & 2011 & Anmyon, Yaean Chungnam (Seed gathering forest) & Seed forest & Forest & no \\
\hline 6 & 2011 & Uiseong, Gyeongbuk (Gumbong lodge) & Forest lodge & Facility & no \\
\hline
\end{tabular}

*: KFSV: Korea Forest Seed \& Variety Center. 
Table 2. Specifications of the Existing Forest Fire Water Supply System

\begin{tabular}{|c|c|c|c|c|c|c|c|c|c|c|}
\hline \hline No. & Location & \multirow{2}{*}{$\begin{array}{c}\text { Amount } \\
\text { of water } \\
\left(\mathrm{m}^{3}\right)\end{array}$} & $\begin{array}{c}\text { Type of } \\
\text { water } \\
\text { tank }\end{array}$ & $\begin{array}{c}\text { Number } \\
\text { of } \\
\text { hydrant }\end{array}$ & $\begin{array}{c}\text { Electric } \\
\text { power }\end{array}$ & $\begin{array}{c}\text { Hose } \\
(\mathrm{mm})\end{array}$ & $\begin{array}{c}\text { Output } \\
\text { pressure } \\
\left(\mathrm{kg} / \mathrm{cm}^{2}\right)\end{array}$ & $\begin{array}{c}\text { Engine } \\
\text { power }\end{array}$ & $\begin{array}{c}\text { Output } \\
(\text { LPM })\end{array}$ & Type \\
\hline 1 & Magoksa temple & 28 & Under & 4 & Common & 40,65 & 2.5 & 100 & 2400 & $\begin{array}{c}\text { Internal } \\
\text { combustion }\end{array}$ \\
\hline 2 & KFSV & 50 & Ground & 3 & Generator & 40 & - & 15 & 300 & Electric \\
\hline 3 & DMZ & 50 & Ground & 3 & & 40 & - & 15 & 300 & \\
\hline 4 & Jwagu forest lodge & 50 & Ground & 3 & & 40 & - & 15 & 300 & \\
\hline 5 & Seed gathering forest & 50 & Under & 3 & & 40 & - & 15 & 300 & \\
\hline 6 & Gumbong forest lodge & 50 & Ground & 2 & Common & 40 & - & 15 & 250 & $\begin{array}{c}\text { Internal } \\
\text { combustion }\end{array}$ \\
\hline
\end{tabular}

소화전 개수, 소화호스규격, 수원의 양, 기동방식을 적용한 것으로 조사되었다.

\section{1 .1 수원의 양}

조사지역 모두 관정을 이용한 지하수를 이용하였고 마 곡사의 수원의 양은 NFSC 109 기준의 2 배인 $28 \mathrm{~m}^{3}$, 다른 설치장소에서는 $50 \mathrm{~m}^{3}$ 의 수원을 확보하였다.

\subsection{2 수조}

지하저수조와 보온 처리된 지상저수조로 각각 설치되었 으며 관정 및 저수지 등으로부터 물을 지속적으로 공급받 을 수 있도록 설치되었다.

\subsection{3 옥외소화전 설치}

소화전 설치개수는 2 4개로 마곡사를 제외한 다른 설치 장소에서는 소화전 설치개소에 대한 산출기준 없이 설치 되었다.

\subsection{4 소화전 관경 및 호스구경}

마곡사의 경우, 옥외소화전 $65 \mathrm{~mm}$ 와 함께 옥내소화전 $40 \mathrm{~mm}$ 호스가 함께 사용하고 다른 설치장소에서는 $40 \mathrm{~mm}$ 호스와 노즐을 사용하고 있었다.

\subsection{5 펌프 성능}

(1) 토출압력: 마곡사의 경우 $0.25 \mathrm{MPa}$ 로 NFSC 109기 준을 적용하였고 다른 지역에서는 호스 관창노즐의 말단 부 토출압력에 대한 기준을 적용하지 않고 $0.6 \mathrm{MPa}, 0.17$ $\mathrm{MPa}$ 등의 각기 다른 자체 시방서 기준을 적용하였다.

(2) 출력: 마곡사의 경우 $100 \mathrm{HP}$, 다른 설치장소에서는 $15 \mathrm{HP}$ 으로 조사되었다.

(3) 토출량: 마곡사의 경우 $2400 \mathrm{LPM}$, 금봉자연휴양림 $250 \mathrm{LPM}$, 다른 지역은 $300 \mathrm{LPM}$ 의 펌프 토출량 성능으로 조사되었다.

(4) 펌프종류: 전기방식의 수중 모터엔진과 내연기관 펌
프가 각각 설치되었다.

\subsection{6 전력공급방식}

수중모터펌프를 이용하는 시설에서는 전기발전기 설비 를 이용하였고 엔진펌프를 사용하는 곳에서는 상용전기를 이용하였으며 비상전원발전설비는 구성되어 있지 않았다.

\section{2 문제점}

\subsection{1 설치기준 미비}

2006년부터 설치, 운영 중인 산불진화용 급수시설 28개 소의 경우, 마곡사를 제외한 모든 지역에서 관련 기준 적 용 없이 자체 시방서 기준으로 설치가 이루어졌다. 이에 다음과 같은 문제점을 파악할 수 있다.

(1) 주요 구성품 및 부속품 성능기준 미비

펌프의 성능기준, 방수압, 방수능력, 수원량, 살수거리 등에 대한 산불진화를 위한 급수시설의 성능기준이 마련 되어 있지 않고 살수장치에 공급하는 배관과 소화호스에 대한 관경, 내압력, 연결관창 사용 등에 대한 기준이 없는 것으로 조사되었다. 현재 사용하고 있는 $40 \mathrm{~mm}$ 호스의 경 우, 무게와 부피로 인해 산악에서 산불진화에 부적합하다. 또한 소화전간의 거리와 소화호스 확보에 대한 고려가 되 어 있지 않았다.

(2) 방호대상 면적 미 평가

28개소 설치 시설의 방호가능 거리 및 면적에 대한 평가 가 이루어져 있지 않았으며 오히려 기동성이 좋은 산불진 화차량보다 성능과 효과가 낮게 평가될 수 있다.

(3) 소화전의 이격거리에 대한 기준 없음

소화전간 이격거리가 짧아 중복될 경우 진화영역이 작 아질 수 있고 이격거리가 넓을 경우에는 진화 공백공간이 발생될 수 있다.

(4) 성능시험 배관 미설치

펌프성능을 평가하기 위한 시험배관, 유량계, 압력계 등 이 설치되지 않아 소화전 말단부에서의 살수시험을 통해 펌프성능을 평가할 수 있다. 


\subsection{2 지상진화자원과의 연계 곤란}

산불진화에 사용되고 있는 기계화산불진화시스템 및 진 화차량에서 사용하고 있는 관 부속품 및 소화호스, 연결 관창 등에 대한 규격이 통일되지 않아 상호이용이 어려운 것으로 조사되었다.

\section{3. 설문조사}

산불예방 및 진화 등에 관한 관계 법령인 “산림보호법” 에는 산불방지를 위한 시설물의 설치나 유지관리에 관한 기준 마련에 대한 관련 조문이 없는 실정이다. 하지만 산 불방지 급수시설은 2006년부터 매년 5개소 이상 '설치 및 유지 관리 기준, 없이 산림지역에 설치되어 실효성 여부와 함께 설치 및 유지관리 상의 문제점이 발생되고 있다. 이 에 설치기준 마련의 필요성과 함께 현장 설치 시 고려되어 야 하는 기능에 대해 산림청 및 지자체 산불담당자 100 명 을 대상으로 설문조사를 실시하였다. 설문은 산불방지 급 수시설 기준에 관한 항목과 산불진화 살수시스템에 관한 항목으로 총 8항목에 대해 실시하였고 설문결과는 다음과 같다.

\section{1 산불방지 급수시설 기준 필요성}

\subsection{1 기준 마련의 필요성}

설문응답자 100 명 모두 필요하다 $(100 \%)$ 로 응답하였다.

\subsection{2 유지 · 보수 관리에 관한 규격화 필요성}

설문응답자 100 명 모두 필요하다 $(100 \%)$ 로 응답하였다.

\subsection{3 유지보수관리비 책정 필요성}

설문응답자 100 명 모두 필요하다 $(100 \%)$ 로 응답하였다.

\subsection{4 우선 보호 및 설치대상지}

인명-휴양림시설 $(16.4 \%)>$ 국가산업시설 $(14.3 \%)>$ 문화재 $(13.8 \%)>$ 산림보호구역 $(10.6 \%)>$ 채종림 $(9.9 \%)>$ 자연환경 보호구역 $(9.7 \%)>$ 군사시설 $(8.6 \%)>$ 시험림 $(7.4 \%)>$ 개인가 옥 $(7.1 \%)>$ 기타보호구역 $(2.8 \%)$ 순으로 응답하였다.

\section{2 산불진화 살수시스템}

3.2.1 산불방지 급수시설 연계가능 시스템

산불방지 급수시설을 이용 가능한 연계시스템으로 $13 \mathrm{~mm}$ 호스연계 $(30 \%)>360$ 도 회전 스프링클러, 이동식 수막설비 (24\%)>방범펜스 수막설비 $(22 \%)$ 순으로 응답하였다.

\subsection{2 산불방지급수전의 적정 호스직경}

산불방지 급수시설에 사용하는 소화호스의 적정 호스직 경에 대한 응답 결과, $25 \mathrm{~mm}(75 \%)>40 \mathrm{~mm}(13 \%)>13 \mathrm{~mm}$ $(11 \%)>18 \mathrm{~mm}(2 \%)$ 순으로 응답하였다. 호스의 이동과 진화를 고려하여 무게와 살수량 등을 고려한 $25 \mathrm{~mm}$ 소화
호스가 현장에서 가장 유용할 것으로 조사되었다.

\section{2 .3 진화호스 사용 반경}

산불방지 급수시설을 이용한 진화호스 사용을 위한 적 정 반경은 $500 \mathrm{~m}(49 \%)>300 \mathrm{~m}(27 \%)>1 \mathrm{~km}(22 \%)>800 \mathrm{~m}$ $(2 \%)$ 순으로 응답하였다. 따라서 산불방지를 위한 급수전 1 개소의 호스거리는 반경 $500 \mathrm{~m}$ 가 적절한 것으로 조사되 었다.

\subsubsection{1인 호스 이동시 적정 무게와 호스길이}

산불진화대원 1 인이 이동 가능한 호스의 적정 무게와 이동거리에 대한 설문조사 결과, $18 \mathrm{~kg}-100 \mathrm{~m}(63 \%)>10$ $\mathrm{kg}-60 \mathrm{~m}(33 \%)>25 \mathrm{~kg}-180 \mathrm{~m}(4 \%)$ 순으로 응답하였다. 따 라서 진화대원 1 인이 이동할 수 있도록 $0.18 \mathrm{~kg} / \mathrm{m}$ 의 소화 호스 무게가 적절한 것으로 조사되었다.

\section{4. 산불방지 급수시설 시스템 제안}

기존 설치된 '산불방지 급수전'은 옥외소화전설비 개넘 의 시설만 설치하였다. 이에 본 연구에서는 산불관계자 설 문조사에서 산불진화 살수시스템 설문결과를 토대로 해당 시설물 및 지역을 산불로부터 보호하고 산불확산을 진화 할 수 있도록 (1) 수관수막설비(Tower Sprinkler System), (2) 산불방지급수전(Hydrant for Forest Fires), (3) 이동형수 막설비(Portable Sprinkler System) 3가지 설비를 제안하 였다.

\section{1 수관수막설비}

수관수막설비는 수관화 및 복사열에 의한 산불확산을 저지 혹은 지연시키기 위하여 산불진행 방향과 직각으로 일정한 폭과 길이의 솦에 입목의 수관부에서 1 시간 이상 살수할 수 있는 설비를 말한다.

\subsection{1 수관수막설비의 구조}

수관수막설비는 주요 구성은 $360^{\circ}$ 회전형 스프링클러 노즐, 피뢰침, 연결밸브(배수밸브 겸용), 송수배관, 타워로 구성되어 있다. 타워형태의 경우 Figure 2에서 보이는 바 와 같이 개별 철골구조물 타워를 연결하여 쌓는 구조로 나 무가 생장에 따라 타워의 높이도 조절할 수 있도록 조립식 형태로 구성되어 있다.

\subsection{2 수관수막설비의 성능}

수관수막설비는 $360^{\circ}$ 회전 스프링클러를 주변 입목 보다 최소 $1 \mathrm{~m}$ 이상 높게 설치하여 반경 $35 \mathrm{~m}$ 이상 살수 하는 장치로 3 대의 수관수막설비를 설치할 경우 길이 $200 \mathrm{~m} \times 40 \mathrm{~m}$ 이상의 살수구역을 구성할 수 있다(Figure 3). 타워시설과 대형스프링클러노즐을 이용한 수관수막설 비의 기능은 지표화 뿐만 아니라 수관화 확산을 방지하기 


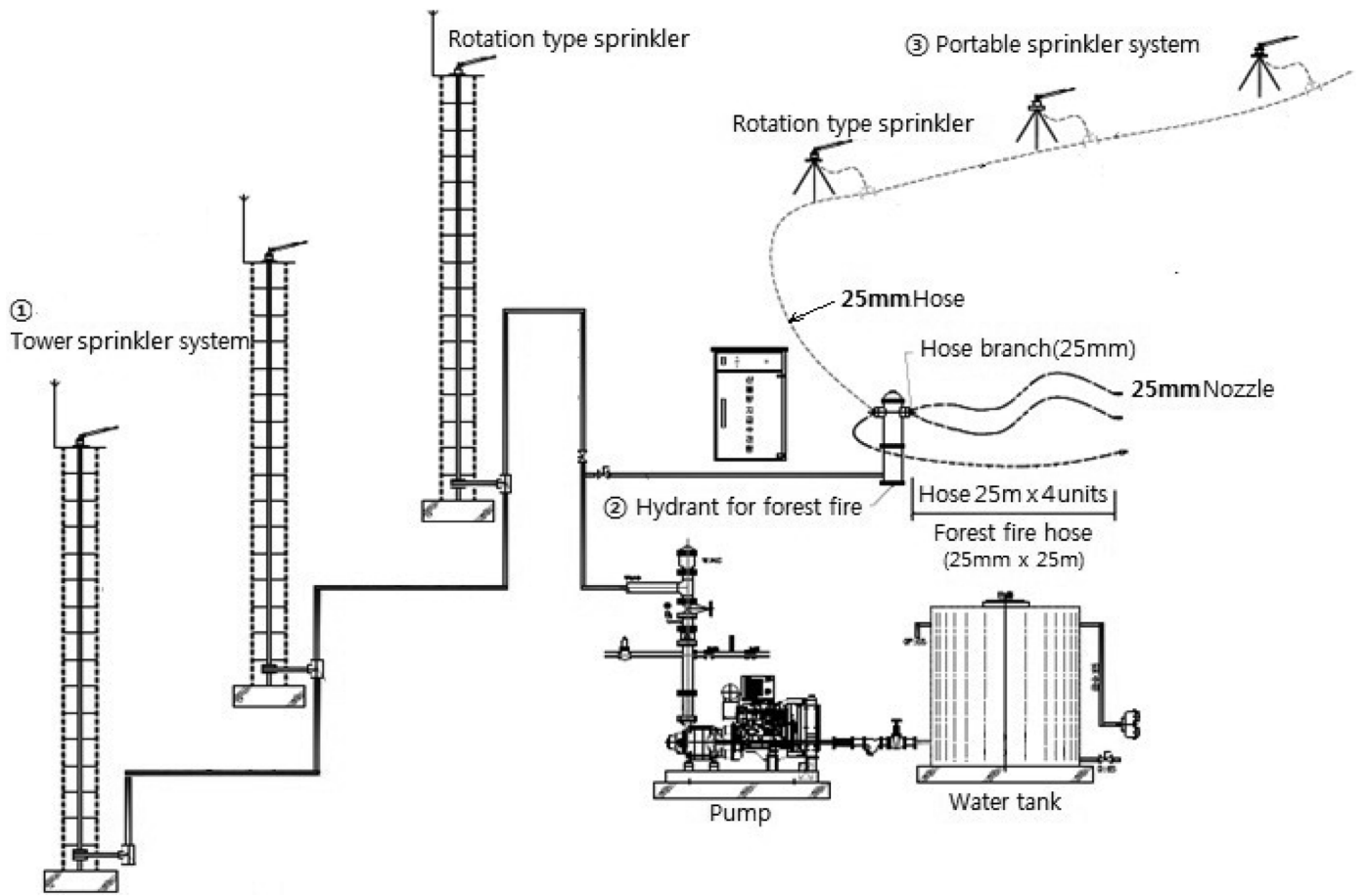

Figure 1. Water supply system for protecting the main facility and forest from forest fire.

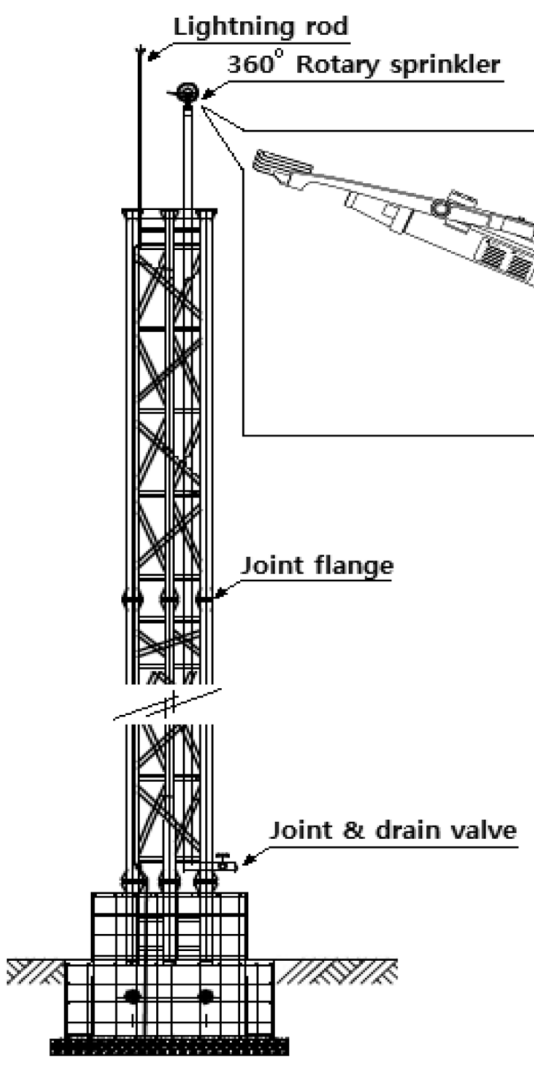

Figure 2. Water sprinkler tower system.

위한 시설물로 반경 $35 \mathrm{~m}$ 살수거리 기준으로 360 도 회전 하면서 $240 \mathrm{LPM}$ 의 물을 Figure 3와 같이 원형으로 살수 하여 산불을 진화 또는 확산되는 산불을 차단하는데 목적

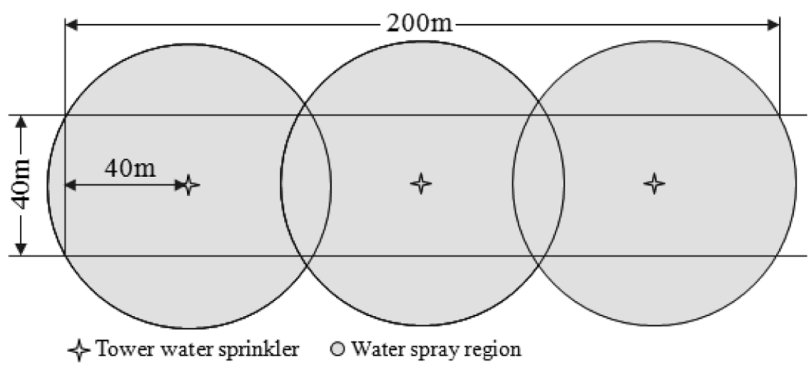

Figure 3. Water spray boundary from water sprinkler tower system.

이 있다.

기존 연구결과에 따르면 지표화의 경우, 단위면적당 $0.1 l$ 의 물을 살수할 경우 진화가 가능한 것으로 연구되어진바 있다 ${ }^{(3)}$. 수관수막설비의 살수량은 단위면적당 $0.25 l$ 로 화 염을 직접 진화할 수 있는 살수량으로 설계되었으며 1시 간 이상 지속적으로 살수할 수 있도록 설계되었다. 또한 화염이 확산 이전에 미리 살수할 경우에는 보다 작은 살수 로 화염전파를 방지할 수 있다.

\subsection{3 수관수막설비의 설치 기준}

(1) 산불이 임상, 입목상태, 경사도, 풍향 및 풍속 등의 여건으로 보호대상 시설물 또는 주요 산림지역 방향으로 진행(확산)이 예상되는 경우, 확산지연과 복사열 차단을 위해 수관수막설비를 설치하여야 한다.

(1) 산불 진행방향은 과거 산불이 발생했던 사례를 참고 하거나 산불발생 위험시기에 설치대상지역에서 발생하는 
바람의 주방향을 현장 조사하여 결정하여야 한다.

(2) 수관수막설비는 바람의 주방행과 직각이 되도록 띠 형태로 설치하여야 한다.

(3) 띠 모양은 바람의 진행방향으로는 최소 $40 \mathrm{~m}$ 이상으 로 하고 직각방향으로는 $200 \mathrm{~m}$ 이상 살수될 수 있도록 설 치하여야 한다.

(2) 수관수막설비는 대상지내 최대 높이의 나무보다 $1 \mathrm{~m}$ 이상 높게 타워를 설치한 후 타워상단부에 분사노즐을 설 치한다.

(3) 수관수막설비에서 분사되는 물은 지표면으로 바로 낙하하지 않고 수피, 잎 등을 충분히 적셔 산불의 복사열 로 인해 수목이 연소되는 것을 방지할 수 있도록 설치하여 야 한다.

(4) 수관수막설비는 다음과 같이 산불방지 숲 가꾸기를 실시한 지역에 설치하여야 한다.

(1) 산불방지 솦 가꾸기는 「목조건축물 주변 산불방지 사업지침」에서 정한 규정에 따라 실시하여야 한다.

(2) 대상지역의 임상, 입목상태, 경사도, 풍속 등에 따라 수관수막시설의 설치기준을 다음과 같이 가감하여 설치하 여야 한다.

- 임상: 낙엽활엽수림 및 혼효림은 설치기준의 최대 $20 \%$ 를 감하여 설치한다.

- 임목상태: $160 \mathrm{~m}^{2} / \mathrm{ha}$ 기준으로 제적 $160 \mathrm{~m}^{2} / \mathrm{ha}$ 의 변화 에 따라 살수량의 $3 \%$ 를 가감한다.

- 경사: 상향 및 하향사면에 따라 중경사는 $10 \%$ 가감하 고 급경사는 $20 \%$ 를 가감한다.

- 풍속: $5 \sim 10 \mathrm{~m} / \mathrm{s}$ 일 경우 $10 \%, 10 \sim 15 \mathrm{~m} / \mathrm{s}$ 일 경우 $20 \%, 15 \mathrm{~m} / \mathrm{s}$ 이상일 경우 $30 \%$ 로 살수량을 증가하여 살 수할 수 있도록 한다.

(5) 수관수막설비는 산불접근 예상시간보다 15 분 전에 가동해야 한다.

(6) 간접연소 방지효과를 증대시키기 위하여 산불진화용 포소화약제를 이용할 수 있는 설비를 추가적으로 설치할 수 있으며 추가설비는 다음과 같이 설치하여야 한다.

(1) 산불진화용 포소화약제의 희석은 펌프측으부터 수관 수막설비의 토출측 배관에 약제혼합배관을 설치하여 토출 압력에 의해 자동으로 포소화약제가 사용농도에 맞도록 희석될 수 있도록 한다.

(2) 약제혼합배관에는 산불진화용 포소화약제 농도조절 장치를 설치하여 자동으로 사용농도에 맞게 혼합될 수 있 도록 한다.

(7) 타워는 기초시설을 하여 고정하고 철재 와이어 등을 이용하여 추가적으로 고정하여야 하며, 형태는 3각 또는 4 각으로 설치하되 풍속 $20 \mathrm{~m} / \mathrm{s}$ 에서 흔들림이나 뒤틀림 없 이 견고하게 제작 설치하여야 한다.

(8) 수관수막설비 타워에 사용하는 재료는 흠이 없는 일 반구조용 압연 강재 또는 스테인리스 강재를 사용하여야 한다.
(9) 수관수막설비 타워는 최대풍속 $30 \mathrm{~m} / \mathrm{s}$ 에 견딜수 있 는 구조여야 하며 자립형 또는 비자립형(와이어 고정형)으 로 설치할 수 있다.

(10) 수관수막설비 타워는 기본적으로 3개를 설치하여야 하며 현지 여건 등을 고려하여 필요한 경우 추가적으로 설 치할 수 있다.

(11) 수관 수막설비 타워에 수관을 결합시켜 타워 최상 단부의 분사노즐에 연결하여야 한다.

(12) 설치한 수관 수막설비 중 산불 진행상황과 전체 수 관 수막설비 분사노즐의 분사상황을 점검할 수 있도록 타 워에는 다음 각 호에 의한 모니터링 감시카메라를 설치하 여야 한다.

(1) 감시카메라 영상은 기계실에서 확인할 수 있어야 한다.

(2) 감시카메라는 산불조심기간에는 반드시 수관 수막설 비에 부착하여 운영하고 그 외의 기간에는 분리하여 보관 할 수 있다.

(13) 수관수막설비에는 일반인이 올라가지 않도록 접근 방지시설을 설치하여야 하며 수관수막설비 설치로 인한 안전사고 등을 예방하기 위한 표지판 등을 설치하여야 한다.

\section{2 산불방지급수전 설비}

산불방지급수전은 일반 소화전과 같은 기능을 가지고

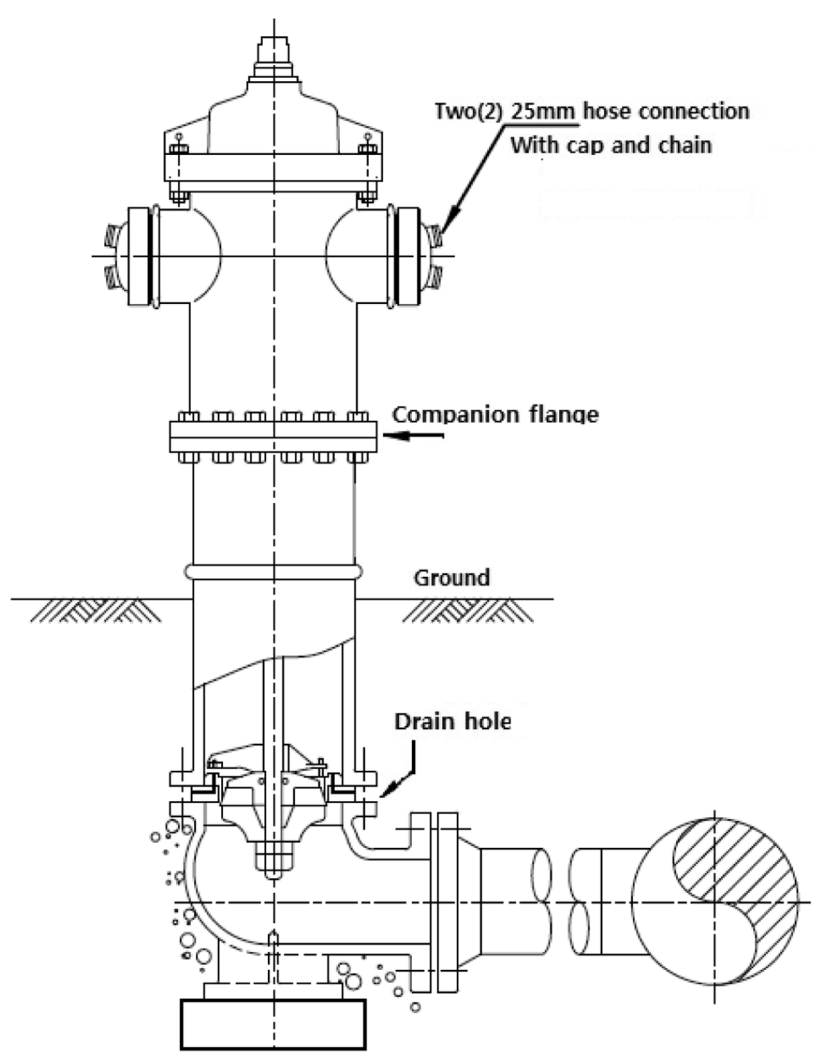

Figure 4. Forest fire hydrant. 
있다. 다만 기존의 소화전은 $40 \mathrm{~mm}$ 또는 $65 \mathrm{~mm}$ 관창을 이용하는 소화전이지만 본 연구에서는 산악지역에서 이동 과 진화를 용이하게 하기위해 Figure 4 와 같이 $25 \mathrm{~mm}$ 소 화호스를 연결할 수 있는 쌍구형 분기구로 이루어져 있다. 산불방지급수전의 주요 설치기준은 다음과 같다.

(1) 산불방지급수전은 기계실로부터 $5 \mathrm{~m}$ 이내에 1 개를 설치하여야 하며 추가 설치할 수 있다.

(2) 2 개 이상의 산불방지급수전의 설치 시에는 급수전간 상호이격 수평거리가 $200 \mathrm{~m}$ 이상이어야 한다.

(3) 산불방지급수전은 지하에 $0.6 \mathrm{~m}$ 이상 매설하여 외부 의 충격 또는 급수시 움직이지 않도록 고정하여야 한다.

(4) 산불방지급수전의 방출구는 $25 \mathrm{~mm}$ 호스 4 개를 연결 할 수 있도록 설치하여야 한다.

(5) $25 \mathrm{~mm}$ 쌍구형 분기구는 개폐장치가 있는 것으로 하 되 수압을 가하는 경우 물이 새거나 균열, 변형 등이 생기 지 않아야 하며 조작이 원활하여야 한다.

(6) 산불방지급수전에는 '산불방지급수전'을 표시하는 표식을 하여야 한다.

(7) 산불방지급수전에 연결하여 사용하는 $25 \mathrm{~mm}$ 소화호 스 말단부의 방수압력은 $0.17 \mathrm{MPa}$ 이상 $0.7 \mathrm{MPa}$ 이하를 확보하여야 한다.

\subsection{1 산불예방호스}

산불예방호스는 산불진화 전용 소화호스로써 규격과 산 악에서 이동을 원활하게 하기위한 이동장치의 규격은 다 음과 같다.
(1) 산불예방호스 규격
- 내경: $25 \mathrm{~mm}$
- 길이: $25 \mathrm{~m} / \mathrm{roll}$
- 무게: $4 \mathrm{~kg} / \mathrm{roll}$ 이하

- 압력: 사용압력 $2 \mathrm{MPa}$, 파열압력 $6 \mathrm{MPa}$

- 재질: 외피, 내피, 연결부로 구성되고 외피는 외부마찰 에 쉽게 마모되지 않아야 하며 나뭇가지 또는 요철에 걸리 지 않도록 산림 내 이동이 용이한 물질로 코팅되어야 하며, 내피는 마찰을 줄여 압력을 높일 수 있는 물질로 코팅되어 야 한다.

- 연결부: Threaded Type(FE24), 알루미늄 합금

(2) 산불예방호스 이동장치

- 무게: $3 \mathrm{~kg}$ 이내

- 기능: 진화대원이 등에 메고 이동할 수 있는 장치로 이동시 자동으로 풀어질 수 있는 기능을 포함하여야 하며 사용 후 호스를 감을 때 호스에 남아있는 물기를 제거할 수 있는 기능을 포함하여야 한다.

\section{3 이동형 수막설비}

이동형 수막설비는 $360^{\circ}$ 회전형 스프링클러를 이용하는 설비로 산불방지급수전에 $25 \mathrm{~mm}$ 산불예방호스를 연결하 여 펌프의 기동과 함께 최대 $250 \mathrm{~m}$ 길이, 최대 $25 \mathrm{~m}$ 폭으 로 동시에 살수할 수 있는 설비이다. 이동형 수막설비의 주요 설치기준은 다음과 같다.

(1) 이동형 수막설비의 분사노즐 또는 회전식 스프링클 러의 살수반경은 $12.5 \mathrm{~m}$ 이상이어야 한다.

(2) 이동형 수막설비 장비는 산불방지급수전 주변 급수 전함 또는 보관실에 구비하여야 하며 설치기준과 구비장 비는 다음과 같다.

- 이동형 수막설비는 호스관경 $25 \mathrm{~mm}$, 호스길이 $25 \mathrm{~m}$ 를 이용하여 $25 \mathrm{~m}$ 마다 분사노즐 또는 회전식 스프링클러 를 1 개씩 최대 10 개를 설치한다.

- 분사노즐 또는 회전식 스프링클러는 분사압력에 움직 이지 않도록 지지대 등으로 고정하여 설치한다.

Table 3. Structure of Installation Guideline for Forest Fire Water Supply System

\begin{tabular}{|c|c|c|l|}
\hline \hline Sections & \multicolumn{2}{|c|}{ Title } & \multicolumn{2}{c|}{ Subjects and Contents } \\
\cline { 2 - 4 } & Articles & \multicolumn{1}{c|}{ Contents } \\
\hline Chapter 1 & General Rules & $1 \sim 4$ & Purpose, Application, Definition, Installation principle \\
\hline Chapter 2 & $\begin{array}{c}\text { Installation of water } \\
\text { supply system }\end{array}$ & $5 \sim 22$ & $\begin{array}{l}\text { Water and water tank, Water supply system, Water sprinkler system, Power } \\
\text { and electric lines. }\end{array}$ \\
\hline Chapter 3 & $\begin{array}{c}\text { Maintenance \& } \\
\text { management }\end{array}$ & $23 \sim 24$ & Qualification for construction and inspection, Operating and management. \\
\hline $\begin{array}{c}\text { Additional } \\
\text { rules }\end{array}$ & $1 \sim 3$ & The date of enforcement, Temporary measure. Delay measure. \\
\hline Attached list & 8 & $\begin{array}{l}\text { 1) Particular guidelines for water tank } \\
\text { 2) Particular guidelines for pressurization water supply equipment } \\
\text { 3) Particular guidelines for capacity of pump and installation } \\
\text { 4) Particular guidelines for a pipe of water supply system } \\
\text { 5) Guideline for addition and subtraction of water supply system } \\
\text { 6) Standards for forest fire hose and portable equipment }\end{array}$ \\
\hline
\end{tabular}




\section{5. 기준제시}

\section{1 산불방지 급수시설 설치기준}

\subsection{1 구성}

'산불방지 급수시설 설치기준'은 Table 3과 같이 구성하 였으며 주요 세부내용을 요약하면 다음과 같다. 여기서, 수원의 양은 Figure 1에서 설명한 3가지 살수설비 중 수관 수막설비를 기준으로 산정하였다.

(1) 기계실 : 펌프, 전원, 송수배관 등의 시설

(2) 수원 : 43.2톤 이상( 3 개 $\times 240 \mathrm{LPM} \times 60$ 분)

(3) 산불방지 주요살수설비

(1) 수관수막설비

(2) 산불방지급수전

(3) 이동형 수막설비

\section{2 산불방지 급수시설 설치 총칙}

\subsection{1 목적}

산불방지 급수시설은 산불로부터 목조문화재, 전통사찰, 자연휴양림 등 시설물과 주요산림지역을 보호하기 위하여 수관화, 복사열로 인한 화염확산을 60 분 이상 저지하거나 규모가 약한 산불을 직접 진화하기위하여 설치한다.

\subsection{2 적용범위}

이 기준의 대상사업은 산림자원의 조성 및 관리에 관한 법률 제 2 조 제 3 호에서 정한 산림사업으로 산림보호법 제 33 조 제 1 항에서 정한 산불의 예방과 진화에 필요한 시설 로써 산불방지 급수시설의 설치, 유지 및 안전관리에 적용 한다.

\section{2 .3 설치원칙}

산불방지 급수시설은 다음 내용에서 정한 원칙에 맞게 설치한다.

(1) 산불발생시 보호대상 시설물과 주요산림지역의 피해 가 최소화 되고 효율적으로 보호될 수 있도록 한다.

(2) 보호대상 시설물과 주요산림지역 주변의 임상, 입목 상태, 경사도, 풍속 등을 감안하여 산불의 강도와 움직임 을 감안하여 설치하여야 한다.

(3) 보호대상 시설물과 주요산림지역 주변의 산불발생 원인, 발생지점 등을 감안하여 위치를 선정하여야 한다.

(4) 산불예방을 위한 이격공간조성, 산불방지 솦가꾸기 사업과 병행하여 설치하여야 한다.

(5) 주변의 자연경관과 조화되도록 훼손을 최소화하여 설치하여야 한다.

\section{6. 결 론}

산불확산을 저지하거나 진화하기 위해서는 공중에서의 산불진화헬기의 의한 살수와 함께 지상진화작업 공조가
필수적이다. 산불확산은 바람의 방향과 세기에 따라 끊임 없이 변화하고 움직이기 때문에 주요 보호시설 및 산림에 대해서는 고정식 산불진화 설비가 반드시 필요하다. 이에 본 연구에서는 기존 산불방지 급수시설에 대한 실태조사 와 전문가 설문조사를 통해 문제점을 개선하고 산불방지 에 보다 효과적으로 활용하기 위해 설치 및 관리에 관한 기준을 제시하였으며 결론은 다음과 같다.

첫째, 기존 산불방지 급수시설 실태조사에서 기존 설치 장치, 부속품 등에 대한 규격 및 성능 기준이 마련되어 있 지 않았고 해당시설물의 방호면적에 대한 평가가 이루어 져 있지 않았다.

둘째, 산불전문가 설문조사에서 모든 설문대상자가 산불 방지 급수시설의 설치 및 유지관리에 대한 필요성에 찬성 하였고 산불방지 급수시설을 이용한 살수방법에 대한 의 견을 제시하였다.

셋째, 사례조사 및 설문조사를 바탕으로 기존 산불방지 급수시설에 수관화, 지표화, 비화 확산방지를 위한 수관수 막설비(살수영역: $200 \mathrm{~m} \times 40 \mathrm{~m}$ ) 설치, 지상진화를 위한 산 불방지급수전과 $25 \mathrm{~mm}$ 산불예방호스 확충, 지표화 진화 를 위한 이동식수막설비(살수영역: $250 \mathrm{~m} \times 25 \mathrm{~m}$ ) 등을 추 가하였다.

넷째, 본 연구에서 제안한 시설의 설치와 운영을 위해 3 장 24조로 구성된 기준안을 마련하였다.

본 연구에서 제안한 '산불방지 급수시설 설치기준'을 이 용하여 산불피해를 저감하는데 기여할 것으로 사료되며 향후, 이 설비에 대한 진화효과분석 및 기술, 운영에 관한 보완 연구가 추가적으로 필요할 것으로 사료된다.

\section{References}

1. D. H. Kim, J. H. Lee, E. S. Kim and J. H. Kim, "Study on Estimating the Unit of Suppression Ability of Forest Fire Suppression Resources", Proceeding of 2011 Korean Institute of Fire Science \& Engineering Spring Conference, pp. 144-147 (2011).

2. S. Y. Lee, D. H. Kim, M. S. Won and M. B. Lee, “Analysis of Forest Fire Spread Rate and Behaviour in Cheongyang, Yeasan of Korea”, Proceeding of 2003 Korea Forest Science, p. 4 (2003).

3. Korea Forest Research Institute (KFRI), "Natural Hazard Prevention Research; Development of Suppression Technique for Forest Fire Damage Reduction", Final Research Report of National Emergency Management Agency (2006).

4. H. S. Park, S. Y. Lee, B. D. Lee and K. S. Koo, "The basic study on forest fire danger assessment for facilities in WUI", Proceeding of 2012 Korean Institute of Fire Science \& Engineering Spring Conference, pp. 456-459 (2012).

5. National Fire Protection Association, "NFPA 1141; Stan- 
dard for Fire Protection Infrastructure for Land Development in Wildland, Rural, and Suburban Areas", 2012 Edition (2012).

6. National Emergency Management Agency, "Regulation for Outdoor Fire Hydrant Systems", National Fire Safety Code 109, No. 2012-126 (2012).
7. Korea Forest Service, "Specifications for Forest Fire Water Supply System in Kangreung National Forest Station", Specification of Construction (2011).

8. Korea Forest Service, "Specifications for Forest Fire Water Supply System in Yangyang National Forest Station", Specification of Construction (2011). 